\title{
CZESŁAW MIŁOSZ I OSIP MANDELSZTAM O SŁOWIE I KULTURZE. SPOTKANIA I ROZEJŚCIA
}

\author{
AGATA STANKOWSKA ${ }^{1}$
}

(Poznań)

\begin{abstract}
Słowa kluczowe: kulturowa funkcja słowa, krystalograficzna teoria rytmu, brak słowa, poetyka i kultura, Czesław Miłosz, Osip E. Mandelsztam
\end{abstract}

Keywords: cultural functions of a word, crystallographic rhythm theory, lack of word, poetics and culture, Czesław Miłosz, Osip E. Mandelshtam

\begin{abstract}
Abstrakt: Agata Stankowska, CZESŁAW MIŁOSZ I OSIP MANDELSZTAM O SŁOWIE I KULTURZE. SPOTKANIA I ROZEJŚCIA. „PORÓWNANIA” 10, 2012, Vol. X, s. 57-70, ISSN 1733-165X. Tematem szkicu jest próba wyjaśnienia przyczyn niejednoznacznego stosunku Czesława Miłosza do liryki Osipa Mandelsztama, znaczonego, z jednej strony, wielokrotnie wyrażanym podziwem dla rosyjskiego akmeisty, z drugiej, zastanawiającym milczeniem o najbardziej wstrząsającej części twórczości autora Stowa $i$ kultury i w końcu obrazoburczym Komentarzem do "Ody dla Stalina". Przedmiotem rozważań stają się tutaj możliwe poetologiczne, a nie "lustracyjne” źródła tej ambiwalencji. Mandelsztam pozostaje Miłoszowi bliski przede wszystkim jako akmeista, kładący nacisk na kulturowe funkcje słowa poetyckiego. Promotor postawy twórczej, która zakłada zachowanie harmonijnej równowagi miedzy uwagą dla rzeczy i dla słowa, postrzeganego jako miejsce spotkania tego, co sensualne, egzystencjalne i historyczne, z tym, co duchowe, uniwersalne i metafizyczne. Dalszy staje się natomiast jako autor Rozmowy o Dantem, w której rozbudowana zostaje teoria krystalograficznego rytmu, silnie akcentująca wagę autonomii i autoteliczności formy poetyckiej. Nie mniej ważnym powodem rozejścia się Miłosza z Mandelsztamem staje się silnie obecny w późnej twórczości autora Zeszystów woroneskich motyw pogłębiana się procesu degradacji, utraty, nieobecności mowy, która zawłaszczona zostaje przez historię i zamiera na ustach ginącego podmiotu.
\end{abstract}

Abstract: Agata Stankowska, CZESŁAW MIŁOSZ AND OSIP MANDELSHTAM ON WORD AND CULTURE. MEETINGS AND DISPERSIONS. "PORÓWNANIA" 10, 2012, Vol. X, p. 57-70, ISSN 1733-165X. The aim of the article is an attempt to explain the reasons of the ambivalent attitude of Czesław Miłosz towards the lyric poetry of Osip Mandelshtam, which, on the one hand, was manifested through admiration for the Russian Acmeist on multiple occasions and,

${ }^{1}$ E-mail Address: stankowska.a@gmail.com 
on the other hand, was marked with puzzling silence in the case of the most shocking works of the author of "Word and culture". Finally, there was the iconoclastic comment on "The Stalin Ode". The main object of these deliberations are potentially poetological - and not revisionist sources of the ambivalence. Mandelshtam remains close to Miłosz mostly as an Acmeist, emphasizing the cultural functions of a poetic word. The promoter of the creative attitude that includes a harmonious balance between the attention to things and a word, considered as the place where one can meet everything that is sensual, existential and historical, as well as spiritual, universal and metaphysical. He becomes more distant as the author of "Rozmowa o Dantem" ["Conversation about Dante"] in which the theory of crystallographic rhythm is expanded with a strong emphasis on the autonomy and autotelic properties of the poetic forms. Another equally important reason of the separation of Miłosz and Mandelshtam is a motive of progressive degradation, loss, lack of speech, which is taken over by history and remains unuttered by the lips of a dying person. This motive is very visible in the late works of the author of "Voronezh Notebooks".

Stosunek Miłosza do Mandelsztama określa zaskakująca ambiwalencja, o której źródła warto pytać. Obu poetów łączy, z jednej strony, wielorakie pokrewieństwo widoczne w namyśle nad fundamentami kultury europejskiej, a także nad rolą, jaką wobec zadanego współczesności dziedzictwa, wielce - jak sądzą obaj zagrożonego, spełniać winna poezja. Miłosz i Mandelsztam są w czynionych w tym obszarze konkluzjach poruszająco zgodni, o czym za chwilę szerzej. Z drugiej strony, autor Kronik nie pozostaje wobec spuścizny rosyjskiego poety bezkrytyczny, sygnalizując swoje wątpliwości zrazu immanentnie, poprzez milczenie o najbardziej wstrząsającej części twórczości autora Zeszytów woroneskich², a później, wyrażając je otwarcie w obrazoburczym i, jak sądzi wielu, wysoce niespra-

2 Jedno ze świadectw, że recepcją twórczości Mandelsztama przez Miłosza rządzi taka właśnie reguła, odnajdujemy w zachowanych w Beinecke notatkach do kursu z literatury europejskiej, w tym lektury tekstów Mandelsztama. Zachowane w Beinecke ślady tych interpretacji opisała ostatnio Monika Wójciak w szkicu "Walka o oddech". Noty o poetach rosyjskich - Annie Achmatowej i Osipie Mandelsztamie, opatrując kwerendę archiwalnych źródeł bardzo interesującą próbą odnalezienia intertekstualnych nawiązań Miłosza do omawianych przez siebie wierszy rosyjskiego poety. Badaczka zwracała uwagę na fakt, iż większość przywoływanych przez autora Ocalenia utworów rosyjskiego poety: Rża dziarsko na pastwiskach rozbrykane konie (Herds of Horses), Z flaszki miodu złotego tak dtugo sączyła się nitka (The Thread of Gold Cordial), Wśród wzgórz Pierii (In the Rocky Foothils of Pieria), Zmierzch wolności (The Filight of Freedom) należy do akmeistycznego okresu twórczości Mandelsztama. Opublikowane zostały w Kamieniu (1913, poszerzone wydania 1916 i 1923) bądź w tomie Tristia (1922). Jedynie utwór Lamarck, który nb. Miłosz opatruje najbardziej zdystansowanym komentarzem, jest utworem późniejszym. Nawet jednak jako taki należy do tak zwanych wierszy moskiewskich, powstałych $\mathrm{w}$ okresie poprzedzającym pierwsze aresztowanie i trzyletnią zsyłkę, której poetyckim owocem stały się słynne Zeszyty woroneskie. Nie sposób nie zauważyć, że te ostatnie, najbardziej chyba znane i wstrząsające utwory autora Kamienia, Miłosz pomija w swoich amerykańskich prelekcjach z literatury europejskiej. 
wiedliwym szkicu o postawie Mandelsztama wobec komunizmu3. Myślę, że ta niejednoznaczność ma głębsze przyczyny. Równie gorąca temperatura podziwu i ostrej krytyki świadczy natomiast o znaczeniu, jakie Miłosz nieodmiennie przypisywał Mandelsztamowi ${ }^{4}$, rozważając wspólne im obu kwestie natury i fenomenologii słowa poetyckiego oraz poszukiwanej - by, jak przed chwilą, posłużyć się parafrazą Mandelsztamowskich formuł - architektury dzieła i człowieka, odzwierciedlających prawdę aktualnego stanu kultury.

W eseistyce autora Ogrodu nauk odnajdujemy wiele świadectw wdzięczności za liryczną obecność twórcy Kamienia, spuentowanych symbolicznie wyznaniem, iż gdyby sam miał zostać którymś z poetów rosyjskich, wybrałby Mandelsztama „z powodu metalicznego dźwięku niektórych jego wersów” ${ }^{5}$. Równocześnie jednak, co skłonna byłabym twierdzić, Miłoszowi obcy pozostaje kierunek ewolucji myśli poetologicznej rosyjskiego twórcy. Zmiany może nie radykalnej, ale jednak znaczącej i widocznej między latami dwudziestymi a trzydziestymi, między szkicami takimi jak Stowo i kultura, Puszkin i Skriabin, Świt akmeizmu, z jednej, a Rozmowie o Dantem, z drugiej strony. Różnica, jaka je dzieli, polega na nieco innym rozkładaniu akcentów w kwestii kulturowej i autotelicznej funkcji słowa poetyckiego, co uzmysławia choćby odmienny stosunek wczesnego i późnego Mandelsztama do symbolizmu.

Najprościej mówiąc, autor Kamienia pozostaje Miłoszowi bliski najbardziej jako akmeista, promotor postawy twórczej, która zakłada zachowanie harmonijnej równowagi między uwagą dla rzeczy i dla słowa, postrzeganego jako miejsce spotkania tego, co sensualne, egzystencjalne i historyczne, z tym, co duchowe, uniwersalne i metafizyczne. Słowo, które jest jednością i dzięki temu pozwala wyrazić, a lepiej byłoby powiedzieć - zgodnie z używaną przez Mandelsztama metaforyką

${ }^{3}$ W latach dziewięćdziesiątych Miłosz pisze i publikuje najpierw na łamach „NaGłosu” (1996, nr 2), a potem w skróconej wersji w "Gazecie Wyborczej", obrazoburczy komentarz do powstałego w Woroneżu wiersza Mandelsztama, znanego jako Oda do Stalina. Na tekst Miłosza odpowiedzieli polemicznie Jerzy Pomianowski, Anatol Najman i Adam Pomorski. Miłosz replikował tekstem Poeta i państwo, tłumacząc, że chodziło mu specyficzny „instynkt państwowy” właściwy inteligencji rosyjskiej. Pisał miedzy innymi: „Mandelsztama nie można uważać za przeciwnika komunizmu, bo zdobycie się na taki świadomy sprzeciw, było nie tylko ponad jego siły, również ponad siły całego literackiego środowiska, które żyło współudziałem w wielkim zbiorowym dziele”. Zob. „Rzeczpospolita” 1996 nr 49 (203). Dodatek tygodniowy „Plus - Minus”.

${ }^{4} \mathrm{~W}$ pismach poety odnajdujemy wiele świadectw zachwytu liryką Mandelsztama, także dowodów, że Miłosz pragnął tę poezję promować w Polsce. Z korespondencji z Konstantym Jeleńskim dowiadujemy się na przykład, że autor Ocalenia namawiał wydawnictwo Ardis, by honoraria z wydania po angielsku książki Ryszarda Przybylskiego o Mandelsztamie, „zużyć na wydanie tej książki po polsku". W: Czesław Miłosz, Konstanty A. Jeleński. Korespondencja. Z faksymiliami listów i wierszy oraz fotografiami zamieszczonymi w ksiażce i na stronie internetowej <www.zeszytyliterackie.pl>. "Zeszyty Literackie", Warszawa 2011, s. 221.

${ }^{5}$ J. Brodski, Rozmowa z Czesławem Miłoszem. „Zeszyty Literackie” 2001, nr 75, s. 65. 
- „ucieleśnić” prawdę rzeczy, człowieka i kultury wyrosłej na gruncie chrześcijańskim. Późniejszy autor Zeszytów woroneskich pisał w pochodzącym z roku 1921 szkicu Stowo i kultura:

Ten, kto podniesie słowo i pokaże go czasom, jak kapłan eucharystię, będzie drugim Jozuem. [...] Żywe słowo nie oznacza przedmiotu, lecz swobodnie wybiera sobie jakby na pomieszkanie to lub inne znaczenie przedmiotu, rzeczowość, miłe ciało ${ }^{6}$.

Kilka lat wcześniej, w programowym Świcie akmeizmu (1913, pierwodruk 1919) kreślił $\mathrm{w}$ polemice $\mathrm{z}$ symbolistami i futurystami program osiągania $\mathrm{w}$ poezji równowagi między różnymi wymiarami słowa. Jego muzyczną formą, świadomym znaczeniem i horyzontem, jaki użyte słowo budzić może w człowieku, jeśli tylko nauczą go tego poeci wydobywający $\mathrm{z}$ mowy wielowymiarową substancję brzmień, sensów i metafizycznych znaczeń. Te trzy wymiary poetyckiego słowa Mandelsztam porównywał do trzech wymiarów przestrzeni, jakie zajmuje każdy dobrze zbudowany dom, pałac, katedra. Sięgając po te architektoniczne obrazy, autor Kamienia podpowiadał, jak sądzę, że słowo poetyckie winno szukać i budować harmonię między ludzką egzystencją, ofiarowaną człowiekowi przyrodą i duchowością, bez której dwie pierwsze pozostają puste i wrogie. Pisał że „Nie ma współzawodnictwa. Jest współudział istnień w spisku przeciw pustce i niebytowi" (Świt akmeizmu, SiK,184). Program ten musiał wydać się Miłoszowi nie tylko piękny, ale też bardzo bliski. Dotykał przecież wszystkich ważnych dla autora Ziemi Ulro kwestii.

Podziwiany twórca akmeizmu stawać się jednak musiał Miłoszowi odleglejszy jako rozbudowujący teorię krystalograficznego rytmu autor Rozmowy o Dantem (1933) -rozmyślań akcentujących o wiele silniej niż uprzednio autonomię i autoteliczność formy.

Wnikając w miarę swych sił w strukturę Divina Commedia, dochodzę do wniosku - pisał w roku 1933 Mandelsztam - że cały poemat stanowi jedną jedyną, jednorodną i niepodzielną strofę. A dokładniej, nie tyle strofę, ile figurę krystolograficzną, czyli zwięźle rozwinięty krystalograficzny temat, ścisłe ciało stereometryczne, przeniknięte nieustannym formotwórczym pędem.

$[\ldots]$

Myślenie obrazowe urzeczywistnia się u Dantego, podobnie jak w każdej prawdziwej poezji, przy pomocy tej cechy materii poetyckiej, którą proponuję nazwać przemiennością lub przeistaczalnością.

$[\ldots]$

Dante włączył światło fonetyki.

${ }^{6}$ O. Mandelsztam, Stowo i Kultura, w: Stowo i kultura. Szkice literackie. Przeł. i komentarzem opatrzył R. Przybylski. Czytelnik. Warszawa 1972, s. 197. Dalsze cytaty szkiców Mandelsztama pochodzą $\mathrm{z}$ tego samego wydania. Podaję w tekście w nawiasie tytuł szkicu, z którego pochodzi przytoczenie, skrót SiK oraz numer strony. 
$[\ldots]$

gdybyśmy słyszeli Dantego, pogrążylibyśmy się w strumieniu energii zwanej w szczególności - metaforą, w swej wymijalności - porównaniem, a jako całość - kompozycją . Strumień ten tworzy określenia tylko po to, aby wzbogacić się ich roztopieniem i nasycić ich powrotem. Aby - ledwie zaszczycone pierwszą radością powstawania - natychmiast utraciły swe pierworództwo, łącząc się z materią, która - płynąc między sensami - zmywa każde określenie.

[Rozmowa o Dantem, SiK, 96, 102, 94, 89]

Z premedytacją przytaczam tę wiązkę cytatów z Rozmowy o Dantem. Uzmysławia ona bowiem jak dalece przeformułował Mandelsztam w latach trzydziestych optykę swego myślenia o poezji ${ }^{7}$. Nie znaczy to oczywiście, że nakreślone wyżej wątki nie pojawiały się we wcześniejszych szkicach poety. Możemy je odnaleźć choćby w Stowie i kulturze oraz w O naturze słowa. W latach 20. ich wymowę dookreślały jednak i ograniczały tezy kulturowe.

Choć nie mamy żadnych zwerbalizowanych explicite świadectw polemicznego stosunku Miłosza wobec późnego Mandelsztama, sądzę, że autor Ocalenia mógł nabierać dystansu wobec myśli rosyjskiego poety właśnie wówczas, gdy pojawiało się $\mathrm{w}$ niej inne zhierarchizowanie dwu korespondujących od początku wątków („kulturowego" i - by tak rzec - „czystopoetyckiego"), a w konsekwencji nieco inny sposób rozumienia niezmiennego wezwania do próby osiągnięcia architektonicznego ładu dzieła i tekstu. Harmonii rozumianej zrazu jako „wykrystalizowana wieczność” [Puszkin i Skriabin, SiK, 192], później jako pochodnej „wewnętrznego obrazu struktury" [Rozmowa o Dantem, SiK, 97], opartej przede wszystkim na fonetyce i intonacji. Wówczas gdy - mówiąc jeszcze inaczej - uwaga kładziona w okresie akmeistycznym na architektonikę kulturowych obrazów, którą po mistrzowsku opisywał Ryszard Przybylski w eseju Wdzięczny gość Boga, przeniesiona zostaje na architektonikę dźwięków i ich „formotwórczy pęd” [Rozmowa o Dantem, SiK,

${ }^{7}$ Gdybym miała w literaturze polskiej wskazać teksty bliskie jakoś Mandelsztamowskim rozważaniom o naturze Dantejskiego rytmu, to nie byłby to szkice Miłosza, lecz Bolesława Leśmiana: Rytm jako światopogląd i U źródeł rytmu, czytane w bezpośrednim nawiązaniu do Z rozmyślań o Bergsonie:

Rytm w poezji stanowi pierwiastek upojeń, oszołomień i uczuciowych, nielogicznych nakazów, którym się stają posłuszne - oddzielne słowa, skupiające się i gromadzące nieświadomie dookoła nieznanej, niepochwytnej a śpiewnej pokusy. Tracą one wówczas określoność i abstrakcyjną organiczność swej treści, wymykając się ścisłym, raz na zawsze utrwalonym prawom logiki i gramatyki, zdobywając na nowo pierwotną swobodę swych nieustannych przemian twórczych i pierwotną zdolność ciągłego dostosowywania się do nieokreślonej i niepochwytnej treści wabiącego je ku sobie istnienia.

- rozpoczynał Leśmian swój programowy w dużej mierze szkic Rytm jako światopogląd. W szkicach Mandelsztama odnajdziemy wiele korespondujących ze słowami Leśmiana fragmentów. Jak choćby ten cytowany przed chwilą fragment z Rozmowy o Dantem [SiK, s. 89].

Zob. B. Leśmian, Rytm jako światopogląd, w: Szkice literackie. Zebrał i oprac. J. Trznadel. PIW, Warszawa 2011, s. 40. 
96], podporządkowane pokrewnej, ale nietożsamej z pierwszą, poetyckiej zasadzie przeistaczalności materiału słownego, najciekawiej opisanej przez Clarence'a Browna, co prawda w odniesieniu do prozy autora Zgietku czasu.

Jeśli mam rację, jeśli Miłosz $\mathrm{w}$ istocie krytycznie odnotowywał zmianę $\mathrm{w}$ planie Mandelsztamowskich rozważań o naturze słowa, byłby to kolejny przypadek potwierdzania stałej dla polskiego poety wstrzemięźliwości wobec wszelkiej liryki, dla której język i wewnętrzna (w tym przypadku intonacyjno-muzyczna) doskonałość i spójność formy, jawią się jako ważniejsze od mowy, a praca poetycka od uprawiania kultury. Liryki, dodajmy, która w wyniku tego przesunięcia tracić może paradoksalnie odporność wobec dyskursów zewnętrznych: jawnie obcych macierzystej tradycji, wsłuchanych bardziej w ducha czasów niż pytania stawiane przez rodzimą kulturę. Stały one w centrum Mandelsztamowskich obrazów „rzeczywistego" 8 antyku i świata jako zamieszkiwanego przez człowieka bożego Pałacu, wypełniających wiersze z Kamienia i Tristiów, a także rozważań o głębokiej helleńskości mowy rosyjskiej, tak charakterystycznych dla wczesnych szkiców Mandelsztama. Przesunięcie, jakie później następuje, objawia się przede wszystkim nasileniem wątków i obrazów związanych ze współczesną, egzystencjalnie doznawaną historią i coraz głębszą tragedią podmiotu, który poddany zostaje teraz coraz wyraźniej współczesnemu, a nie „poprzecznemu” wymiarowi czasu, o którym czytaliśmy w szkicu Puszkin i Skriabin. Równocześnie w tekstach okołopoetyckich, przede wszystkim we wspomnianej Rozmowie o Dantem, z większą mocą wybrzmiewać zaczynają tezy dotyczące jakości czysto poetyckich, ujęte przy tym $\mathrm{w}$ sposób nasuwający skojarzenia $\mathrm{z}$ symbolizmem i formalizmem. Mandelsztam napisze $\mathrm{w}$ tym kluczowym dla jego rozmienienia poezji $\mathrm{w}$ latach trzydziestych szkicu na przykład, że „historyczne podejście do Dantego jest równie niezadowalające jak polityczne czy teologiczne" (Rozmowa o Dantem, SiK, 99). W zamian za to wskazywać będzie konieczność wyjaśniania „wewnętrznego oświetlenia Dantejskiej przestrzeni, dające się wywieść tylko z elementów struktury” (Rozmowa o Dantem, SiK, 98). Wzywać będzie do podjęcia „studiów nad wzajemną zależnością uniesienia twórczego i tekstu" (Rozmowa o Dantem, SiK, 132).

Takiemu przeniesieniu akcentu na poetycki walor towarzyszyć musiało choćby minimalne zmniejszenie uwagi dla tego, co i z jakiego powodu winno się "Wcielać" w słowie. Autor Przeciw poezji niezrozumiatej tę zmianę akcentów postrzegać mógł, w dokonywanej po latach lekturze, jako zgodę na swoistą degrada-

${ }^{8}$ Antyk pełni jak wiadomo bardzo ważną rolę w liryce autora Kamienia. W jego eseistyce odnajdujemy także kilkakrotnie zarzut niewłaściwego odwoływania się do tego dziedzictwa. I tak w szkicu Wiek dziewiętnasty (SiK, 173-174) czytamy między innymi: „Wiek XVIII odrzuciwszy odziedziczone po epoce chrześcijaństwa źródło światła, powinien był problem ten rozwiązać na nowo. I rzeczywiście rozwiązał go w szczególny sposób. Przyznał się do pogaństwa, które sam wymyślił, i do antyku, który nie miał nic wspólnego ani $\mathrm{z}$ antykiem rzeczywistym, ani $\mathrm{z}$ antykiem filologów, lecz był utylitarną fantazją stworzoną dla zaspokojenia pilnych potrzeb historycznych". 
cję, a w każdym razie osłabienie kulturowej funkcji poezji. Sam powtarzał przecież - jak pamiętamy - po wielokroć, że ów niepożądany efekt koresponduje, a może wręcz jest skutkiem ograniczania rozumienia słowa, które musi zawsze „dążyć do serca rzeczy”, a jednocześnie "być zawsze po stronie mythos" 9 . Konsekwentnie zwalczał więc nie tylko jaskrawe świadectwa, ale też minimalne sygnały - wysłyszane słusznie, czy niesłusznie - które sugerować by mogły osłabianie kulturotwórczej mocy słowa, jaką sam - znów podobnie jak wczesny Mandelsztam - wiązał przede wszystkim z wątkami historiozoficznymi, antropologicznymi i eschatologicznymi ${ }^{10}$. Miłosz był i pozostał przekonany, że pojawiającej się tu ewentualnie straty nie może zrekompensować największa nawet dbałość o jakość czysto poetycką.

Podejrzewam, że tu właśnie tkwi przyczyna milczenia polskiego poety o późniejszej twórczości autora Zeszytów woroneskich, a także głębokie źródło (poetologiczne, a nie „lustracyjne"11) zaskakującej tezy Miłosza o nieodporności Mandelsztama na dyskursy i postawy własnej epoki. Tezy, na której sformułowanie miały zapewne $\mathrm{w}$ jakimś stopniu wpływ znane polskiemu poecie interpretacje amerykańskich badaczy twórczości autora Zeszytów woroneskich. Mam tu na myśli szczególnie pracę Gregorego Freidina A Coat of Many Colors (University of California Press, Berkeley 1987), którą Miłosz w swoim Komentarzu do „Ody dla Stalina" cytował, nie podając jednak jej wiele mówiącego podtytułu: Osip Mandelsztam and His Mythologies of Self-Presentation ${ }^{12}$. Do grona tych lektur (choć tu nie posiadamy potwierdzenia ich znajomości) należą być może także dwa nawiązujące do książki Freidina szkice Donalda Davie'go: From the Marches of Christendom, w którym pojawia się przeciwstawienie polskiego i rosyjskiego poety na gruncie odmiennego podejścia do herezji, oraz podobną $\mathrm{w}$ wymowie recenzję tego samego badacza z książek Aleksandra Fiuta Moment wieczny i A Coat of Many Colors Gregorego Freidina właśnie.

Nawet jeśli pominąć te pozycje, a samą wyostrzoną retorycznie tezę nieco osłabić, bez większego ryzyka przypuszczać możemy, że Miłosz jako czytelnik liryki Mandelsztama nie mógł pozostać obojętny na zapisane w niej pospołu,

${ }^{9}$ Cz. Miłosz, Postscriptum. „Teksty Drugie” 1990, nr 5/6, s. 174.

${ }^{10} \mathrm{Na}$ temat „utopii filologicznej” przedstawionej w O naturze stowa Mandelsztama, w kontekście rozwoju tej idei w kulturze rosyjskiej XX wieku pisał Bardzo interesująco Jens Herlth w artykule Ocoбенности филологического самосознания в русской культуре ХХ века: Мандельштам, Розанов, Авериниев. Ученые записки Казанского университета. Серия Гуманитарные науки 2011, Том 153, кн. 2.

${ }^{11} \mathrm{~W}$ napisanym w reakcji na liczne polemiki z Komentarzem do „Ody dla Stalina" tekście Dlaczego napisałem „Komentarz do 'Ody dla Stalina'”. Poeta i państwo Miłosz zaznaczał, że napisał swój komentarz „bez najmniejszych zamiarów lustracyjnych - całkowicie poza kategorią "powinien był - nie powinien był«". Zob. „Rzeczpospolita” 1996, nr 49 (203), 7-8 grudnia. Dodatek tygodniowy „Plus - Minus”.

12 Rodzaj nawiązań Miłosza do tej książki opisywała Clare Cavanagh w szkicu Afterword: Martyrs, Survivors, and Sucess Stories, Or The Postcommunist Prophet, w: Lyric Poetry and Modern Politisc. Russia, Poland, and the West. Yale University Press New Haven, London 2009. 
a dramatycznie skontrastowane: akmeistyczny hymn wyrażający wiarę w słowo i następującą po nim, wybrzmiewającą na jego tle tym dobitniej, opowieść o dramacie mowy. Mowy najpierw zawłaszczanej, a potem utraconej. Oceniać mógł tę ewolucję jako dowód swoistej rezygnacji. Także jako wyraz wyrzeczenia się koniecznego dystansu - "stylu" - tak istotnego dla pokonywania rozpaczy, której doznanie sam zawsze tonował i skrywał.

W rzeczy samej, późna liryka Mandelsztama bardzo wyraźnie odnotowuje świadomość pogłębiania się procesu degradacji, utraty, nieobecności słowa. Zaniku mowy i rozpadu człowieka. W planie biograficznym towarzyszy jej najpierw długotrwałe zamilknięcie poety (związane najpewniej także z chorobą). Nie ono jednak jest tutaj rozstrzygające. Nawet wówczas, gdy Mandelsztam ożywiony pobytem $\mathrm{w}$ Armenii zaczyna znowu pisać, utwory opowiadające o utracie i niemożliwości słowa pojawiają się coraz częściej, by w Wierszach woroneskich świadczyć już tylko o nieodwołalności tego procesu. Równocześnie myślenie o słowie powiązane zostaje w konsekwencji doznawanego dramatu, nie - jak wcześniej z rozważaniami o fundamentach kultury (co Miłoszowi musiało być i pozostało bliskie), ale z sytuacją samego podmiotu, który podlega degradacji i nie może już mówić, a co najwyżej czuć. O ile w dedykowanym Annie Achmatowej wierszu z 1931 Mandelsztam pisał jeszcze:

Uchroń moją mowę na zawsze za posmak nieszczęścia i dymu,

Za smolnie kolistą cierpliwość, za dziegieć mozołu wytrwały.

Tak woda w nowogródzkich studniach powinna się czernią wydymać,

By się w niej wigilijna gwiazda odbiła siedmioma płetwami, ${ }^{13}$

o ile, $\mathrm{w}$ innym wierszu $\mathrm{z}$ tego samego roku powtarzał $\mathrm{z}$ nadzieją na ziszczenie: „Niech z dna nocy polarnej błękitny lis wyjdzie, / Niech zalśni w mroźnej piękności" ([** Tak, za chwate tych dni...], przeł. Jerzy Pomianowski, s. 159), o tyle w czasie, gdy głębia stalinowskiego mroku tężała coraz bardziej, przesłaniając widok nieba i świetlistych pejzaży, świadczył już niemal bez wyjątku o niemożności zrealizowania tych pragnień. Pragnień wciąż jeszcze pamiętanych, ale już swoiście niebyłych, bo niedostępnych i niemożliwych do spełnienia, właśnie z powodu braku mowy. Późne wiersze Mandelsztama coraz dobitniej oddają postępującą niemoc tego, który pragnie śpiewać, ale śpiewać już nie może. Tego, kto doskonale zna wartość i potrzebę odebranego mowie ładu, ale kto nie potrafi już jej wokół odnaleźć i zobaczyć wbrew doznawanej historii.

${ }^{13}$ O. Mandelsztam, [***Uchroń moja mowę na zawsze...] przeł. Stanisław Barańczak, w: Nikomu ani stowa... Wybór i posłowie T. Klimowicz. Przeł. S. Barańczak, A. Drawicz, G. Gieysztor, P. Hertz, M. Jastrun, K. A. Jaworski, M. Leśniewska, L. Lewin, A. Mandalian, A. Międzyrzecki, T. Nyczek, S. Pollak, J. Pomianowski, W. Słobodnik, J. Waczków, W. Woroszylski, B. Zadura. Wydawnictwo Literackie, Kraków 1998, s. 169. Dalej w tekście, cytując wiersze Mandelsztama, podaję w nawiasie tytuł, bądź incipit oraz nazwisko tłumacza i numer strony z podanego wyżej wydania. 
Ludziom potrzebne światło i błękit przestrzeni, Chleb, śnieg Elbrusu, biel obłoków.

Ale nie mogę naradzić się z nikim, A sam nie umiem go odnaleźć -

Takich przejrzystych płaczących kamyków

Nie znają Krymy ani Urale.

Ludziom potrzebny jest wiersz tajemnie - pokrewny,

By na dźwięk jego wiecznie się budzili

I w fali lnianowłosej, kasztanowej, śpiewnej -

$\mathrm{W}$ jego oddechu twarze myli.

[*** Tkwię w pajęczynie świetlistych promieni - ...], tłum. Stanisław Barańczak, s. 209, podkr. - A.S.

Podmiot wierszy zamieszczonych w Zeszytach woroneskich po wielokroć zdradza swoje ogołocenie z mowy. Samotny i niemy wsłuchuje się we własną bezradność.

Śpiewam, gdy krtań wilgotna, dusza schnie

I w miarę mokry wzrok, i proste rozeznanie.

Czy zdrowe wino? zdrowy bukłak? krew

Czy zdrowa? w krwi Kolchidy kołysanie?

Ścieśnia się pierś, bez języka, niemowa,

Już nie ja śpiewam - oddech śpiewa mnie -

W górniczych schronach słuch i głucha głowa.

[*** Śpiewam, gdy krtań wilgotna ...], tłum. Mieczysław Jastrun, s. 215, podkr. - A.S.

O tej utracie słowa, nieobecności mowy jako ważkim motywie poezji swego męża pisała także w poruszający sposób Nadieżda Mandelsztam w eseju Mozart $i$ Salierii, łącząc to spostrzeżenie, co dla mnie w kontekście stawianej powyżej tezy niezmiernie ważne, z uwagami o poddawaniu się przez autora Rozmowy o Dantem rytmowi, który samo słowo swoiście zagłuszał i skrywał.

U Mandelsztama - pisała Nadieżda Jakowlewna - wsłuchiwanie się w siebie przechodziło w końcu w mamrotanie i zamiast jednego zwycięskiego dźwięku pojawiała się rytmiczna całość. [...] proces twórczy w swoim początkowym stadium przedstawiał się więc w sposób następujący: wstępny niepokój, brzmiący zlepek formy, czyli „bezdźwięczny chór" z trudem wyłowiony przez słuch, zaczątkowe mamrotanie, w którym już ujawnia się pierwiastek rytmiczny - i w końcu -pierwsze słowa. Zamiast niepokoju tryumfuje nareszcie radość pierwszych odkryć. I po tym wszystkim na poetę spada nowe nieszczęście: trzeba szukać zgubionego słowa ${ }^{14}$.

14 N. Mandelsztam, Mozart i Salieri oraz inne szkice i listy. Wyb., przeł. i komentarz R. Przybylski. Sic, Warszawa 2000, s. 38-39. 
Nie trzeba dodawać, że Miłosz tego progu nigdy nie przekroczył, nawet w swoich najdramatyczniejszych utworach niwelując rozpacz właśnie dzięki wierze, że mowę, podobnie jak człowieka, można uratować, zachowując dystans między dramatem a wyrazem, między językiem, jakim czyni z mowy historia a słowem, w którym poeta pomimo i wbrew traumie świadczy z uporem o możliwości ładu, piękna i tego, co akmeistyczny Mandelsztam nazywał architekturą słowa. Symboliczna wydaje się tu strofa kończąca stosunkowo wczesny, powszechnie znany wiersz autora Miasta bez imienia poświęcony wiernej mowie. W utworze tym także nie brakuje przecież słów o zwątpieniu. To ostanie okazuje się jednak nieostateczne, a posłanie poetyckie, polegające na choćby cząstkowym ocalaniu mowy i ładu, zachowuje swą aktualność.

Są chwile kiedy wydaje się, że zmarnowałem życie.

Bo ty jesteś mową upodlonych,

mową nierozumnych i nienawidzących

siebie bardziej może od innych narodów,

mową konfidentów,

mową pomieszanych,

chorych na własną niewinność ${ }^{15}$.

- pisze Miłosz, by chwilę potem, w końcówce wiersza, odnaleźć sposób chronienia słowa przed degradującym wpływem historii. Role między podmiotem a ojczystym językiem zostają tu zresztą - jak pamiętamy - odwrócone. Polszczyznaojczyzna, traktowana przez emigranta jako enklawa tego, co rodzinne i własne (to wątek bardzo silnie obecny także w eseistyce wczesnego Mandelsztama ${ }^{16}$ ), przedstawiona zostaje ostatecznie jako przedmiot terapeutycznych działań poety.

${ }^{15}$ Cz. Miłosz, Moja wierna mowo, w: Wiersze. T. 2. Kraków - Wrocław 1985, s. 181.

${ }^{16} \mathrm{~W}$ wielu szkicach Mandelsztama pojawiają się tezy o konieczności odkrywania w poezji prawdziwego, „żywiołu mowy rosyjskiej” (O poezji, SiK, s. 23). Autor Kamienia określa go mianem głębokiego hellenizmu i rozumie jako zdolność słowa do wyrażania i ucieleśniania "tajemnicy dobrowolnego wcielenia". W szkicu O naturze stowa, poeta napisze, że mowa rosyjska stała się „ucieleśnionym dźwiękiem i ucieleśnioną mową" (SiK, s. 28). Także i w tym przypadku Mandelsztam posługuje się, czego nie sposób przeoczyć, chrześcijańską figurą wcielenia: „Słowa, które stało się ciałem”, zachowując równocześnie swą głęboko materialną (brzmieniową) i duchową (sensotwórczą, metafizyczną) materię i substancję. Zadaniem poezji jest według akmeisty właśnie pielęgnacja tak pojętej natury słowa. Zadaniem poety i każdego dbałego o rodzimą kulturę Rosjanina jest natomiast uprawa filologii. Niezwykle pięknie i trafnie tę wyrażoną w figuratywnym języku myśl Mandelsztama wyraził Ryszard Przybylski, pisząc: „Hellenizm to przede wszystkim miłość do filologii. Skoro esencja człowieka ukryta jest $\mathrm{w}$ artykułowanej mowie, to człowiek, który szanuje samego siebie musi również kochać słowo. Nienawiść do słowa to nienawiść do człowieka". Podobne sądy o konieczności pielęgnacji „geniuszu języka", który winien w poezji być bardziej słyszalny niż "geniusz jej autora." Odnajdujemy w pismach innego ojca nowoczesnego klasycyzmu - T.S. Eliota. Zob. R. Przybylski, Skrzydlata twierdza nominalizmu, w: Wdzięczny gość Boga. Esej o poezji Osipa Mandelsztama. Libella, Paryż 1980, 
Moja wierna mowo,

może to jednak ja muszę ciebie ratować.

Więc będę dalej stawiać przed tobą miseczki z kolorami

jasnymi i czystymi jeżeli to możliwe,

bo w nieszczęściu potrzebny jakiś ład czy piękno ${ }^{17}$.

Ten motyw przewija się przez całą twórczość autora Drugiej przestrzeni. Nawet $\mathrm{w}$ tym niezwykle ciemnym $\mathrm{w}$ tonacji tomie, otwarcie ujawniającym skrywaną rozpacz polskiego twórcy, Miłosz napisze po latach:

Tylko nie wyznania. Własne życie

Tak mnie dojadło, że znalazłbym ulgę

Opowiadając o nim.

[...]

Więc co mnie powstrzymuje?

$[\ldots]$

Nawet gdybym dojrzał do skargi hiobowej,

Lepiej zamilczeć, pochwalać niezmienny

Porządek rzeczy. Nie, to co innego

Nie pozwala mi mówić. Kto cierpi, powinien

Być prawdomówny. Gdzież tam, ile przebrań,

Ile komedii, litości nad sobą!

Fałsz uczuć odgaduje się po fałszu frazy.

Zanadto cenię styl, żeby ryzykować ${ }^{18}$.

W jednym z listów do Konstantego Jeleńskiego odnaleźć możemy fragment, w którym poeta wyjawia jeszcze jeden - kto wie, czy nie najważniejszy - powód tego swoistego tonowania pesymizmu i wiedzy. Jest nim obawa przed byciem poza kulturą.

Ciężkie mam życie. I jeżeli sobie coś wyrzucam w zakresie mojego pisania, to że mój pesymizm nie został tak ujawniony, jak był powinien - tylko, że wtedy przekracza się pewną granicę jakiegoś ludzkiego decorum i jest się wyraźnie poza kulturą ${ }^{19}$ [podkr. - A.S]

- pisze Miłosz i zaraz potem wypisuje fragment własnego wiersza.

s. 36. Zob. też T.S. Eliot, Kto to jest klasyk?, w: Kto to jest klasyk $i$ inne eseje. Przeł. M. Heydel, M. Niemojowska, H. Pręczkowska, M. Żurowski. Znak, Kraków 1998, s. 77.

17 Cz. Miłosz, Moja wierna mowo, op. cit., s. 182.

${ }^{18}$ Cz. Miłosz, Przepis, w: To. Kraków 2000, s. 36.

${ }^{19}$ Z listu Czesława Miłosza do Konstantego Jeleńskiego (30 VII 79), w: Czestaw Miłosz, Konstanty A. Jeleński. Korespondencja. Z faksymiliami listów i wierszy oraz fotografiami zamieszczonymi w ksią̇̇e i na stronie internetowej www.zeszytyliterackie.pl, op. cit., s. 215. 
O piękno, błogosławieństwo: was tylko zebrałem

Z życia, które było gorzkie i pomylone,

Takie, w którym poznaje się swoje i cudze zło.

Zachwyt porażał mnie i tylko zachwyt pamiętam.

Wschody słońca w nieobjętym listowiu,

Kwiaty otwarte po nocy, trawy bezbrzeżne,

Niebieski zarys gór dla krzyku hosanna.

Ile razy myślałem: nie to jest prawda ziemi.

Od przekleństw i zawodzeń skąd tutaj do hymnów?

Dlaczego chcę udawać, kiedy wiem tak dużo?

Ale usta same wychwalały, nogi same biegły,

Serce mocno biło i język rozgłaszał wielbienie ${ }^{20}$.

Oczywiście, przeciwności i lęków, z jakimi zmagał się Miłosz, nie sposób porównywać z dramatem Mandelsztama. Niemniej autor Ziemi Ulro miał prawo pozostać wstrzemięźliwy wobec obecnego $\mathrm{w}$ wierszach rosyjskiego twórcy przejścia od wpisanego w manifesty akmeizmu projektu mowy jako narzędzia budowania architektonicznego gmachu kultury do odmiennego jednak zamysłu, kładącego nacisk na wewnętrzną formę. Od programu przywracania liryce „zasady tożsamości”, w polemice z symbolistami i futurystami: programu, który pozwalał wówczas Mandelsztamowi powiedzieć, że oto „Kultura stała się kościołem” [Stowo i kultura, SiK, 194] do wiary, że zachowująca "jedność" i spójność forma poetycka, dążąca - przypomnę - do "przeniknięcia samej siebie” zaoferować może poecie coś więcej. Co? Być może wolność, której nie ma w świecie? Obietnicę bezpiecznego trwania we wnętrzu „,słownej przestrzeni”"21, rządzącej się własnymi prawami, swoiście wsobnej i dlatego niepodległej. Argumenty takie raczej by Miłosza nie przekonały. Tym bardziej, że paradoksalnie ten "czysty” język, zbyt wyraźnie i bez ocalającego dystansu opowiadał prawdę podmiotu, któremu epoka, jej historia i utracona mowa niosły śmierć. Wiersze woroneskie autor Ocalenia czytać mógł przeto, jak sądzę, jako dalekie, a nawet sprzeczne z wyznawanym przez siebie przez całe życie pragnieniem, by poezja, odnosząc się do tego, co trwałe i piękne, potwierdzała niezachwianie nasz hymniczny sprzeciw wobec śmierci, pomimo grozy historii, pomimo podmiotowego pesymizmu i filozoficznych konstatacji o prymacie nicości. Nawet w chwilach największych zwątpień i bolesnych rozczarowań stanem planety i ludzkiej kondycji, nie tylko podtrzymujących, ale wzmagających aktualność pytania "skąd zło?", Miłosz nie wyrzekł się swego "ekstatycznego zachwytu", nie porzucił, choć w niektórych tomach, wyraźnie przyciszał właściwy sobie "kod hymniczny"22.

20 Ibidem, s. 216.

${ }^{21}$ Właśnie to Mandelsztamowskie określenie użyte przez Miłosza w Ziemi Ulro świadczy niezbicie o znajomości przez polskiego poetę Rozmowy o Dantem. Zob. Cz. Miłosz, Ziemia Ulro. Znak, Kraków 1994, s. 158.

22 Zob. D. Pawelec, Kod hymniczny w poezji Czesława Miłosza. „Pamiętnik Literacki” 2011, z. 2. 
Czy Miłosz był w tych odczytaniach Zeszytów woroneskich i ocenach Mandelsztama sprawiedliwy? Szczerze mówiąc, nie sądzę, choć nie można mu odmówić swoistej konsekwencji. Warto też zauważyć, że prowadząc swój „spór" z autorem Lamarka²3 miał chyba głębsze powody, niż te ujawniane i prowokacyjnie wyrażane w Komentarzu do „Ody dla Stalina”. Nawet jednak w tej drugiej perspektywie - przedstawianej tu konieczności jedynie sygnalnie i bez rozbudowanej argumentacji - pomijał jeden z ważnych, ba, kluczowych, jak sadzę, wątków myśli Osipa Emiljewicza.

Otóż w pismach okołopoetyckich Mandelsztama z lat dwudziestych pojawia się myśl, że teleologię i kulturowy sens poezji i sztuki w ogóle (nawet tak asemantycznej jak muzyka) można zbudować nie tylko immanentnie, w oparciu o podejmowane $\mathrm{w}$ niej problemy i pytania kluczowe dla kondycji człowieka i stanu kultury. Rozważanych, dodajmy - do czego równie nieustannie namawiał Miłosz - w zdystansowanym, ironicznym dyskursie „formy bardziej pojemnej”, w której indywidualny głos ginie $\mathrm{w}$ splocie wielu dialogizujących ze sobą perspektyw. W poetyckich traktatach, którym towarzyszą epifanijne - „świetliste” powiedziałby Mandelsztam - opisy istniejącego bytu, róży, która jest różą i lisa, na którego - nauczał Miłosz - trzeba patrzeć, bo po prostu , ,jest". Jądrem i nośnikiem owej teleologii, pisał młody akmeista, może być także i w wielu przypadkach pozostaje jako rozstrzygający los samego twórcy. Poruszający przykład takiego sądu Mandelsztam zawarł w pochodzącym najpewniej z 1915 lub 1916 roku szkicu Puszkin i Skriabin. Pisał w nim:

Pragnę mówić o śmierci Skriabina jako najwyższym akcie jego twórczości. Wydaje mi się, że śmierci artysty nie należy wyłączać z łańcucha jego twórczych osiągnięć. Jest to przecież ostatnie końcowe ogniwo. $Z$ tego całkowicie chrześcijańskiego punktu wiedzenia śmierć Skriabina jest zdumiewająca. Jest niezwykła nie tylko jako przykład pośmiertnego wybuchu legendy artysty w oczach mas, lecz jako źródło całej jego twórczości, jako jej teleologiczna przyczyna [Puszkin i Skriabin, SiK, s. 186].

Moglibyśmy powiedzieć, że tymi słowy Mandelsztam otwierał proroczo perspektywę na własną, nie przeczuwaną przecież jeszcze wówczas śmierć. Nie tylko jednak i nie przede wszystkim. W szkicu Puszkin i Skriabin rosyjski poeta podpowiadał także - utrzymując wyraźnie kulturową perspektywę - że taka lektura dzieła artystycznego jest możliwa jedynie wówczas, gdy spojrzymy na sztukę europejską z poszanowaniem dla tradycji, na jakiej wzrosła, z pytaniem i z pamięcią o kulturowych źródłach, których jest owocem. Autor Kamienia, podobnie jak Eliot

${ }^{23}$ Zob. Cz. Miłosz, Spory przyrodników. „Tygodnik Powszechny” 2004, nr 7. W szkicu tym Miłosz stawiał dwie skontrastowane ze sobą tezy. Z jednej strony pisał, że wiersz Lamark jest „przede wszystkim [...] dowodem skrajnego załamania się poety, marzeniem o cofnięciu się do poziomu istot najniższych na drabinie ewolucji i zdobycie w ten sposób anonimatu jako sposobu przetrwania". Z drugiej strony, podkreślał - zgodnie z własnymi sądami o roli poezjowania - że wiersz ten jest „przykładem zmagania się poezji z treścią intelektualną i jako taki może być odtrutką przeciw poezji, która nie oznacza nic poza sobą". 
i jak Miłosz, wielokrotnie podpowiadał, że źródłem tym jest chrześcijaństwo. Czynił to - warto podkreślić, bo cecha ta wyróżnia go spośród wymienionych twórców - posługując się z niezwykłą odwagą, nie zważając na niebezpieczeństwo stylistycznego nadmiaru, figurami wcielenia i odkupienia. Zanim użył pierwszej z nich, by opisać w roku 1922 r. helleńskiego ducha mowy rosyjskiej, wykorzystał ją właśnie we wcześniejszym szkicu zainspirowanym odejściem Skriabina.

Artyści chrześcijańscy - pisał wtedy Mandelsztam - są jakby wyzwoleńcami idei odkupienia. To nie są niewolnicy, ani kaznodzieje. Cała nasza kultura licząca dwa tysiące lat, dzięki cudownej łasce chrześcijaństwa to świat wypuszczony na woln o ść, aby igrał, radował swą dusze i dobrowolnie „naśladował Chrystusa”. [...] Żywiąc sztukę, oddając jej swe ciało, proponując jej zupełnie realny fakt odkupienia w charakterze niewzruszonej zasady metafizycznej, chrześcijaństwo nie żądało niczego w zamian. Dlatego kulturze chrześcijańskiej nie grozi niebezpieczeństwo wewnętrznego zubożenia. Kultura jest niewyczerpana, nieskończona, ponieważ triumfując nad czasem ciągle gromadzi łaskę $\mathrm{w}$ ogromne chmury i napełnia je życiodajnym deszczem. [Puszkin i Skriabin, SiK, s. 188-189, podkr. - A.S.]

Zaiste obraz to daleki od chrześcijańskiej ortodoksji, ale też ucieleśniający dramatycznie jedno z najważniejszych źródeł kultury europejskiej, w epoce "naukowego światopoglądu" wielce niepewnych, będących raczej przedmiotem zakładu niż pewności. Nie przez przypadek właśnie w zakończeniu cytowanego szkicu, w bezpośrednim związku z tezą o śmierci jako o ostatnim ogniwie twórczości, Mandelsztam formułował słynne zdania o "poprzecznym wymiarze czasu” i „harmonii jako wykrystalizowanej wieczności”. Zdania, które, dodajmy, nadawały ostateczny sens jego nauce o trzech wymiarach słowa, opisywanej w Świcie akmeizmu, a nie poddawanej przez Miłosza nigdy w wątpliwość. Piszę o tym dlatego, ponieważ ta koincydencja uświadamia, że waga kulturowego celu, tak dobitnie formułowanego $\mathrm{w}$ okresie akmeistycznym, a w późnych wierszach cokolwiek wyciszona, ujrzana być może dzięki temu inaczej. Mandelsztam podpowiada przecież w Puszkinie i Skriabinie, że skupiona na sobie liryka, sztuka autonomiczna, nawet taka, która w bezpośredni sposób nie ma zamiaru włączać się w kulturowy dialog (co zresztą w sensie ścisłym udziałem Mandelsztama nigdy się nie stało), może swój społeczny i kulturowy sens odzyskać dzięki prawdzie dramatu doświadczanego i przyjmowanego przez twórcę. Nawet bowiem jeśli nie słuchać już głosu poety, któremu odebrano mowę i który ją utracił lub odmówił sobie prawa, przemawiać może jego milczące, udręczone ciało. „Tkanki naszego świata są odnawiane przez śmierć" [Puszkin i Skriabin, SiK, 191] - pisał Mandelsztam - „Pamiętać za wszelką cenę! Zwyciężyć zapomnienie, chociażby za cenę śmierci - oto dewiza sztuki Skriabina, oto heroiczne dążenie jego sztuki!" [Puszkin i Skriabin, SiK, s. 191]. Myślę, że w niedostatecznie silnym poszanowaniu tej prawdy, wypowiedzianej i przyjętej jeszcze przez Mandelsztama - akmeistę, kryje się największa niestosowność Miłoszowego Komentarza do "Ody do Stalina". 